\title{
Shanghai, a Creative Fashion System Under Construction
}

Sabine Chrétien-Ichikawa

\section{OpenEdition}

\section{Journals}

Electronic version

URL: http://journals.openedition.org/chinaperspectives/6789

DOI: 10.4000/chinaperspectives.6789

ISSN: 1996-4617

Publisher

Centre d'étude français sur la Chine contemporaine

Printed version

Date of publication: 1 September 2015

Number of pages: $33-41$

ISSN: 2070-3449

\section{Electronic reference}

Sabine Chrétien-Ichikawa, «Shanghai, a Creative Fashion System Under Construction », China Perspectives [Online], 2015/3 | 2015, Online since 01 January 2017, connection on 28 October 2019

URL : http://journals.openedition.org/chinaperspectives/6789; DOI : 10.4000/chinaperspectives.6789

(c) All rights reserved 


\title{
Shanghai, a Creative Fashion
}

\section{System Under Construction}

\author{
SABINE CHRÉTIEN-ICHIKAWA
}

\begin{abstract}
Since the 1990s, Chinese entrepreneurs in the textile and apparel industry have confronted rapid change and increasing pressure stemming from mature foreign entrants and changing local demand. Facing multiple challenges to differentiate and keep a competitive advantage, they are being transformed into creativity-driven organisations. The transition of the Chinese clothing industry into a fashion-creating system entails a specific environment. Not only is it under construction, but its evolution may impact the global fashion economy.
\end{abstract}

KEYWORDS: Shanghai, fashion industry, Chinese entrepreneurs, fashion system, creative industries, design.

n China, as in many countries, textile production has been an engine for industrial growth. From the reforms of the 1980s onwards, strategies aimed at the development of light industries were included in the Five-Year Plans after policies focusing primarily on heavy industries. Textile and clothing companies then came to the forefront to create wealth and employment. As a consequence, Chinese companies, for the most part state-owned enterprises (SOEs), were urged to obtain orders and currency from developed economies. This rapid growth involved achieving technical transfers to transform an obsolete industry based on mass production of low-quality products. Deng Xiaoping's historic Southern Tour in 1992 further accelerated an upsurge in new enterprises. The industry grew dramatically, and several domestic textile producers took the lead in transforming themselves into garment makers and later into retailers and clothing brands.

Since the 2000s, another factor has become crucial for the development of the industry: innovation and creativity embodied in fashion. Fashion, as one of the key industries of the creative economy, ${ }^{(1)}$ is highly visible through its communication, and is playing a significant role in the birth of the modern consumer society that the government aims to achieve. Shifting first from heavy to light industries, then from textile production to clothing, and more recently transitioning into creativity-centred fashion brands, entrepreneurs have faced all the challenges of the modern world fashion industry in a quarter of a century.

This paper presents the transition of the Chinese clothing industry into a fashion-creating system. The main purpose is to identify how globalisation and the economic and social environment of fashion in Shanghai have created new challenges for local players and a need to embrace innovation. The arrival of new entrants was one of the major reasons for the acceleration of a new demand for large, medium, and small companies to find growth opportunities and differentiate amidst a tougher market environment. After supplying developed markets and global consumers with cheap products since the 1980s, the majority of these manufacturers faced the risk of collapse if they did not rapidly integrate new principles into their value chain from design to distribution.
The consequences of this competitive environment vary according to the scale of analysis and the type of actors studied. Under the leadership of the state, manufacturers, distributors, and fashion intermediaries have each found ways to adapt and to further integrate innovation, value creation, and branding. In the scope of this paper, we shall focus mainly on two levels: the eco-system of the sector, and companies. We will see what kinds of pressures and tensions have appeared, and some of the emerging alternatives. We present new evidence on this sector in the last two decades. The frame of analysis was drawn from an interdisciplinary approach as well as from a comparison with other mature fashion countries in the West and with Japan. A body of academic literature, (2) recent books on the subject, trade data, company resources, and the economic press were supplemented with ten qualitative interviews with professionals. The paper also aims at bridging the gap between fashion studies, organisational studies, and Chinese studies. Furthermore, research on the textile and clothing industry generally takes a macro economical perspective, or focuses on labour issues, value chains, ${ }^{(3)}$ and international trade networks. We focus on the micro level of Chinese apparel makers and designers, which has not yet been studied by business historians. ${ }^{(4)}$ They play a key role in the production of creative goods and brands, and in the upgrading of the "made in China" image.

In the first part we present the concept of a fashion system as our theoretical framework. Secondly, we recall the historical background of Shanghai as a textile centre and fashion city. In the third part, we describe the challenges for producers and designer brands to differentiate themselves

1. UNESCO, UNESCO Creative Economy Report, Paris, 2008.

2. See for instance Fashion Practice, Vol. 4, No. 1, 2012, special issue on contemporary Chinese fashion.

3. Olivier Cattaneo, Gary Gereffi, Sébastien Miroudot, Daria Taglioni, "Joining, Upgrading and Being Competitive in Clobal Value Chains: Strategic Framework," Policy research working paper 6406, The World Bank Poverty Reduction and Economic Management Network, International Trade department, April 2013.

4. The most recent books on this industry take an ethnographic standpoint, or a design perspective. See Zhao Jianhua, The Chinese Fashion Industry: An Ethnographic Approach, London, Bloomsbury, 2014; and Gemma Williams, Fashion China, New York, Thames \& Hudson, 2015. 
in a changing environment. The fourth part describes the eco-system under construction in Shanghai, and the role of intermediaries in its current evolution as a creative city.

\section{Shanghai fashion system}

The term "fashion system" holds different meanings depending on the scientific discipline. It was popularised by French semiotician and philosopher Roland Barthes, who analysed the mechanisms of language by which meanings are produced and circulate in the fashion media. ${ }^{(5)}$ It is also generally used to describe the fashion eco-system of the industry as a whole, and its long value chain. Our approach to a system is influenced by the interdisciplinary theory of systems developed by Bertalanffy. ${ }^{\left({ }^{6}\right)}$ This theory provides a framework to describe a group of components and the relations or forces between them, and was therefore chosen to examine the burgeoning Chinese fashion system and elements of its organisational structure. Moreover, we refer to the concept of sistema di moda used by Italian authors Saviolo and Testa ${ }^{(7)}$ and the Japanese sociologist Yuniya Kawamura ${ }^{(8)}$ in their specific observation of the fashion industries of Italy and France respectively. Indeed, sociologists have observed that creative fashion stems from an eco-system with similar elements found in textile regions that transformed into fashion cities around the world. (9) As a matter of fact, the presence of specific actors and their interaction over a certain period of time in a specific place and region with a strong textile background can potentially develop and mature into a fashion hub. These actors are institutions, associations, cultural gatekeepers, and companies that produce, design, and distribute. They interact with local consumer demand for sophisticated products, and benefit from cultural dynamism. ${ }^{(10)}$ Yuniya Kawamura analyses the fashion capital of Paris as it acquired an international status and a leading role up to the present. Richard Florida's analysis of creative cities further supports this idea and highlights the interaction of various players, both public and private, in a specific location and time, crystallising into fashion capitals. In Europe and the United States the fashion industry resulted from a long process. In China, the industry achieved remarkable growth on a wider scale in only three decades since 1978, supported by an average growth in GDP of $10 \%$ annually.

\section{Creative city Shanghai: The transition to a creativity-driven economy}

Shanghai offers an exceptional example of a creative fashion system under construction. The institutions, private and public actors, financial investors, creative companies, and designers described by Kawamura all exist and have the potential to contribute to the upsurge of a fashion-forward industry and market. Innovation plays an increasing role at every level of the system. After years of supplying foreign markets according to customers' design input, the need to differentiate through innovation and branding has accelerated in companies. Branding is related to the company's vision, mission, and identity. ${ }^{(11)}$ Fashion gatekeepers (e.g., buyers and fashion editors) are those who evaluate a city's influence on global creation and trends. In order for a brand to come to their notice, a high level of sophistication and artistic statement is expected, as well as originality and influence, sometimes with no short-term return on investment. Transforming the city into a fashion capital has become one of the goals of local industry players, but we argue that it cannot be self-proclaimed. Shanghai is still in the midst of this process, and it is difficult to find outstanding or influential trends there compared to other world fashion cities. ${ }^{(12)}$

Our hypothesis is that the transition occurring in China, and more specifically in Shanghai, can be defined as a transformation from a clothing industry into a fashion industry in its own right, which is able to launch original local concepts and brands, take root in culture, and create a bridge toward modernity and genuine innovation. Taking into account the boom in Japanese fashion, for instance, we refer to designers and brands that could be perceived, acknowledged, and identified as Chinese with a local and global influence. This creative wave or momentum has not yet been reached, but Shanghai is unique among mainland Chinese cities in its combined local and foreign influence over the last century and a half, its power of attraction, and several factors seen in other fashion cities. Richard Florida explains the importance of a city's ability to attract talented and creative people to develop an innovative industrial environment. This city can. How is Shanghai developing this environment?

One of the outcomes of being a financial centre and business platform is becoming a world capital and then an Asian fashion capital. The decision to reinforce Shanghai's role as a global city was supported by the Central Government as early as in 1992. The 1999-2000 master city plan included a list of objectives, among which one addressed creativity specifically and the fashion-related industries indirectly. For instance, attention was paid to the soft and hard infrastructure of culture through the building of theatres, concert halls, libraries, and other cultural institutions. In 2004, UNESCO launched the Creative Cities network, which Shanghai joined in 2010. Member cities are recognised as creative hubs that promote socio-economic and cultural development, and which connect "diverse communities to create a healthy urban environment." (13) The objectives are to strengthen the creation, production, distribution, and enjoyment of cultural goods and services at the local level; to promote creativity and creative expression especially among vulnerable groups, including women and youth; to enhance access to and participation in cultural life as well as enjoyment of cultural goods; and to integrate the cultural and creative industries into local development plans. ${ }^{(14)}$ Since then, such policies have been applied throughout the city, creating a favourable environment for fashion creation and consumption. Michael Keane was among the pioneers that followed them. ${ }^{(15)}$

5. Roland Barthes, Le système de la mode (The Fashion System), Paris, Seuil, 1967

6. Ludwig von Bertalanffy, General System Theory: Foundations, Development, Applications, New York, George Braziller, 1969

7. Stefania Saviolo et al., Le Imprese del Sistema moda: Il management al servizio della creatività (Businesses of fashion: Management at the service of creativity), Milan, Etas Editions, 2005.

8. Yuniya Kawamura, The Japanese Revolution in Paris Fashion, New York, Berg, 2004.

9. Christopher Breward and David Gilbert (eds), Fashion's World Cities: Cultures of Consumption, Oxford \& New York, Berg, 2006.

10. Sabine Chrétien-Ichikawa, La Réémergence de la Mode Chinoise et le Rôle du Japon (Reemergence of Chinese Fashion and the role of Japan), unpublished PhD thesis, Paris, EHESS, 2012.

11. Jean-Noël Kapferer, Les Marques: Capital de l'Entreprise (Brands: Capital of the Enterprise), Paris, Éd. de l'Organisation, 2007.

12. Interview with Mrs. Irene Lee, WGSN Shanghai office, May 2012.

13. UNESCO, "Creative cities network mission statement," September 2013

14. Ibid.

15. Michael Keane, Created in China: The Great New Leap Forward, London and New York, Routledge, 2009. 
In a country with 1.3 billion inhabitants, 780 million employees (in 2009), (16) and a disposable income for urban households of 19,000 yuan in 2010 compared with 6,280 yuan in 2000 , the potential for growth has created new opportunities. In 2010, out of 13,471 yuan per capita expenditure, $10.7 \%$ was spent on clothing. Shanghai, with 23 million inhabitants, is one of the major apparel markets. It could be argued that Shanghai is mature enough to soon be considered a well-developed fashion system in its own right, if we consider its market size, local demand, and the overwhelming presence of foreign brands and retail development. The main element missing is the output of creative fashion.

Fashion creativity integrates social change and aesthetic evolution, and it can impact national identity beyond the city of Shanghai. (17) But several questions remain unanswered concerning the potential emergence of alternative creative models under a strong planned economy. What might occur when foreign brands, international concepts, and design agencies enter large cities, and local consumers acquire higher purchasing power, sophisticated tastes, and more information, and start traveling? Will generations of returnees, and the sons and daughters of 1990s entrepreneurs, make different decisions under domestic political, legal, and economic constraints? Can innovation be planned in fashion as it was in heavy industries or high tech? Soft power ${ }^{(18)}$ can be planned, but we may argue that in other countries it also stems from individual initiative and free collaboration between people and artistic disciplines at the grassroots level. Fashion historian and sinologist Antonia Finnane argues, "It may be the case that state-sponsored nationalism militates against both a more interesting approach to cultural heritage on the part of designers and a more receptive climate for Chinese fashion on international catwalks." (19)

\section{Shanghai as historic textile centre and fashion city}

Shanghai has been a centre for the trade and production of cotton since the Ming dynasty, ${ }^{(20)}$ and China's main textile centre. The Opium War (1839-1842) and the Nanjing Treaty enhanced its role as an international harbour open to the world. It became an emblematic location for Chinese and modern Western civilisation to meet. (21) Indeed, the history of modern Chinese fashion is deeply rooted in this city and in its openness to other cultures through trade and the establishment of foreign concessions by expatriates since the mid-nineteenth century. ${ }^{(22)}$ Studying the birth of the Chinese fashion industry is therefore tantamount to recounting the history of Shanghai. The pillar of the textile industry in Shanghai was the basis for the flourishing of tailor shops and for the emergence of probably the first "fashion capital" of Asia. The transformation of Shanghai into a dynamic economic, industrial, and cultural city created the environment for an entrepreneurial spirit to emerge in the clothing industry as well as in the manufacturing of consumer goods and Chinese brands. (23)

The first entrepreneurs of the Chinese textile industry were from the region of Shanghai, extending to Ningbo, one of the five ports designated by the Treaty of Nanjing. In the first quarter of the twentieth century, Shanghai fashion was as refined as in other countries. (24) Some authors argue that Ningbo tailors were also part of the dynamism of the city's fashion scene, (25) especially on Nanjing Road. In 1919, 434 of Shanghai's commercial establishments were importing luxury products, and $79.7 \%$ of them were concentrated in the city centre. ${ }^{(26)} \mathrm{A}$ long tradition and knowhow in textiles had attracted Western merchants for centuries, particularly for silk. As in other world cities such as New York, Shanghai was at that time a vibrant financial centre (27) and a city of migrants, (28) factors favourable to the emergence of a fashion industry. Furthermore, fashion phenomena are linked to social distinction, ${ }^{(29)}$ which was present at the time.

In the 1920s and 30s, about $40 \%$ of China's external trade was concentrated in Shanghai. ${ }^{(30)}$ In the first quarter of the twentieth century there was a concentration of banks, investors, advertising agencies, and artists, and a strong local demand that facilitated the growth of fashion: "(...) the fashion industry by definition exists by virtue of capitalism and industrialization." (31) Shanghai's role as economic and cosmopolitan capital and its openness to the world attracted talent in business, design, fashion, performing arts, and "creative industries" at that time. ${ }^{(32)}$ It was in Shanghai that one could observe avant-garde fashion and women wearing high heels and tight qipao dresses. It also attracted innovations such as the Singer sewing machine and the Japanese weaving loom Toyoda (today's Toyota). Foreign influences, both in business and culture, an entrepreneurial spirit, and cheap local labour accelerated the development of fashion.

In 1949, almost all businesses were private in Shanghai. Size or largeness was seen as an ultimate goal for enterprises in modern China at that time, although "the number of small centres of economic power inherited by the Communists in 1949 in Shanghai was greater than any socialist government had ever faced in a single city previously." (33) Large mills and small family businesses stood side by side, but under the Communist era of the ensuing years, they gradually came under government control with more or less resistance. As a consequence, small family enterprises based on handicrafts were absorbed into large, centralised corporations or cooperatives under a planned economy. Under collectivisation, father-to-son skill

16. National Bureau of Statistics of China, BRICS Joint Statistical Publication 2011, 2011, p. 24.

17. Melissa Aronczyk, Branding the Nation: The Global Business of National Identity, Oxford and New York, Oxford University Press, 2013.

18. Joseph S. Nye Jr., Soft Power: The Means to Success in World Politics, New York, Public Affairs, 2004.

19. Antonia Finnane, "China on the Catwalk: Between Economic Success and Nationalistic Anxiety," The China Quarterly, No. 183, 2005, pp. 587-608.

20. François Gipouloux, La Méditerranée asiatique. Villes portuaires et réseaux marchands en Chine, au Japon et en Asie du Sud-Est, XVle-XXle siècle, Paris, CNRS Editions, 2008, pp. 198-199. English translation by Jonathan Hall and Dianna Martin, The Asian Mediterranean: Port Cities and Trading Networks in China, Japan and Southeast Asia, 13th-21st Century, Cheltenham and Northampton, Edward Elgar Publishing, 2011, 407 pp.

21. Marie-Claire Bergère, Histoire de Shanghai (History of Shanghai), Paris, Fayard, 2002, pp. 9-10.

22. Antonia Finnane, Changing clothes in China: Fashion, History, Nation, New York, Columbia University Press, 2008.

23. Karl Gerth, China Made: Consumer Culture and the Creation of the Nation, Cambridge and London, Harvard University Press, 2003

24. Antonia Finnane, Changing clothes in China: Fashion, History, Nation, op. cit.

25. Carles Brasó-Broggi, Shanghai and the Cotton Industry in China: The case of Dafeng, PhD thesis, Barcelona, Pompeu Fabra University, 2010, p. 100.

26. Marie-Claire Bergère, L'Âge d'or de la bourgeoisie chinoise (The Golden Age of Chinese Bourgeoisie), Paris, Flammarion, 1987, pp. 116-117.

27. Christopher Breward, David Gilbert (eds), Fashion's World Cities: Cultures of Consumption, op. cit.

28. Nancy Green, Ready-to-Wear and Ready-to-Work: A Century of Industry and Immigrants in Paris and New York, New York, Duke University Press, 1998.

29. Georg Simmel, "Fashion," The American Journal of Sociology, Vol. 62, No. 6, 1957 [1904], pp. 541-548.

30. Marie-Claire Bergère, Histoire de Shanghai (History of Shanghai), op. cit., p. 160.

31. Antonia Finnane, Changing clothes in China: Fashion, History, Nation, op. cit.

32. See Richard Caves, Creative Industries: Contracts between Art and Commerce, Cambridge, MA, and London, Harvard University Press, 2000.

33. Lynn T.White, "Low Power: Small Enterprises in Shanghai, 1949-67," The China Quarterly, No. 73, 1978, pp. 45-76. 
transmission was replaced by group training. (34) Nonetheless, a lack of cadres and the diversity and number of small entities made it difficult to control them all, even as late as 1956. ${ }^{(35)}$ In the municipal archives of the 1960s, concern for the preservation of crafts and quality is palpable. ${ }^{(36)}$ Later on, the years of the Cultural Revolution further weakened the fashion industry and consumption, erasing social differentiation and the fashions associated with bourgeois lifestyle. More than other cities, Shanghai epitomised values to be eradicated. Ironically, the danger of wearing inappropriate attire increased the attention of people to their "(...) appearance in an unprecedented manner." (37)

\section{Thirty years of catching up with world fashion standards}

In 1978 the economic reforms included the development of the textile industry. A decade later, the textile and apparel makers still lagged behind international standards, and foreign orders took long to process. The country strove to improve product quality and to increase exports to Europe and the United States, but lacked entrepreneurs who were able to respond to fast change, unlike Hong Kong and Taiwan: "Coming out of nowhere in the past few years, China has become one of the world's biggest textile and apparel exporters," noted a journalist at the end of the 1980s. (38) The increase in textile and apparel exports was vital to the modernisation plan, as well as to earning foreign currency, which reached US\$9.56 billion in 1987. (39) By then industry leaders were already expressing the need to move "up-market." As few factories were able to provide quality product finishing, fabrics, or packaging, and delays could reach months, foreign buyers provided parts of garments (down to thread and needles) in order to avoid problems. However, state-owned factories remained outdated and bureaucratic, and cheap labour costs did not necessarily compensate for problems with production quality and delivery.

In the second half of the 1990s, Chinese apparel companies experienced increased pressure from external and internal environments. On the one hand, the easing of trade laws enabled foreign entrants to settle more easily into the Chinese market. On the other, domestic consumption started to become a driver of economic growth, creating new fashion-oriented purchasing behaviour to be addressed by local producers. Per capita GDP increased about five-fold between 2000 and 2012, from 7,858 yuan to 38,420 yuan. ${ }^{(40)}$ Internally, companies implemented several solutions to counteract these new constraints. Some of the largest ones with fine business acumen were able to adapt their organisations and hire foreign consultants and designers to help them improve their processes in terms of product design, (41) branding, merchandising, and supply chain.

In the 2000s, increasing competition put greater strain on local fashion companies and foreign-funded retailers. The decade saw two major events impacting the textile and fashion industry: the entry of China into the WTO in 2001, (42) and the end of the quota system on textile imports in 2005. On a micro level, producers and retailers saw their margins decrease with surges in rents and material costs, ${ }^{(43)}$ and in labour costs due to legal and social policies. Optimisation of productivity became a key success factor for domestic companies competing with global brands such as Nike or fast-fashion brands such as Zara (Inditex Group), which brought advanced supply chain systems and branding expertise. Another foreign entrant in 1996 was the Danish group Best Seller, one of the leaders of today's Chinese apparel market. The Chinese independent branch operated 6,500 stores in 400 local cities as of 2014, and employed 70,000 people locally. ${ }^{(44)}$ It was able to open 700 stores a year and closed about 300 in 2013. ${ }^{(45)}$ These events demonstrate the rapid speed of development and competition required in this market to stay afloat and to be attractive to the increasingly fashion-savvy new urban consumer. How did Chinese players anticipate and react to this trend?

\section{Apparel makers differentiate through creativity}

The relaxation of market entry regulations was beneficial to Chinese consumers, who started to be exposed to value-added imported items with more fashion content. Nonetheless, on the managerial side, traditional methods inherited from SOEs had to be reconsidered in order to integrate modern principles, comparable to multinational corporations, in order to avoid losing market share. As an example, Bosideng 波司登 and Lily are among the leaders of the local apparel production and retail scene in terms of turnover and distribution coverage, but they are not recognised as fashion brands. Indeed, in mature markets, the fashion industry is characterised by a high rate of renewal, seasonal change, and a balance between aesthetic input and industrialised processes. It is the outcome of relations between production and consumption, art and commerce. ${ }^{(46)}$ It relies on constant innovation, from the fibre industry upstream to the product and retail environment downstream. One of the best examples of a balancing of art and commerce is the Italian fashion system, where a strong network of fashion designers working with industrial organisations (such as Armani) built their competitive advantage in the upmarket sector by combining "rational management" with "emotional management." (47)

According to Michael Porter, a company's competitive advantage is mainly the result of two options: cutting costs or differentiation. ${ }^{(48)}$ Following the economic reforms, the Chinese clothing industry positioned itself with the first option and saw remarkable growth in the 1980s and thereafter primarily as a result of cheap labour costs. This strategy attracted orders from Europe, the U.S., and Japan. Local companies manufactured

34. Geoffrey Cowlland, "Learning Craft Skills in China: Apprenticeship and Social Capital in an Artisan Community of practice," Anthropology \& Education, Vol. 43, No. 4, 2012, pp. 358-371.

35. Lynn T. White, "Low Power: Small Enterprises in Shanghai, 1949-67," art. cit., p. 55.

36. Consultation of Shanghai Municipal archives of the 1960s, including the Mayor's speech, and exhibition reports.

37. Juan Juan Wu, Chinese Fashion from Mao to Now, Oxford \& New York, Berg, 2009, p. 2.

38. Julia Leung, "China's Textile-Export Explosion Falters - Quotas, Production woes make some buyers shy away," The Wall Street Journal, Eastern Edition, 12 September 1988.

39. Ibid.

40. National Bureau of Statistics, 2013 China Statistical Yearbook, Beijing, China Statistic Press, 2013.

41. Interview with Mrs. Wang, chief pattern maker of Metersbonwe apparel brand, Shanghai, 8 December 2008.

42. Bradley A. Feuling, "Developing China Sales and Distribution Capabilities," China Business Review, 1 July 2010.

43. Li \& Fung Research Centre, "Textile and Apparel Clusters in China," China Industrial Cluster Series, No. 5, May 2006

44. Danish Chamber of Commerce in Hong Kong, "The story of Best Seller Fashion Group China Allan Warburg," 29 May 2014.

45. Interview with Mr. Laurent Cochet, supply chain consultant, Shanghai, January 2014

46. Regina Lee Blaszwyck (ed.), Producing Fashion: Commerce, Culture, and Consumers, Philadelphia, University of Pennsylvania Press, 2007

47. Stefania Saviolo et al., Le Imprese del Sistema moda: Il management al servizio della creatività (Businesses of fashion: Management at the service of creativity), op. cit.

48. Michael Porter, The Competitive Advantage, New York, Macmillan, 1985. 
according to foreign design instructions and then exported their merchandise under foreign labels, with no need to recruit an internal creative team. The economic development and wage increases of the 1990s, as well as the entry of foreign competition, created an urgent need to progressively shift business management towards the second option of differentiation. Implementing a differentiation strategy means creating an advantage over the competition apart from cutting costs and is mainly based on creating value. In this sector, value translates into upgrading quality, investing in innovation and creativity, launching or acquiring fashion concepts and brands, and possibly appealing to international markets. How did Chinese companies integrate these parameters?

As a matter of fact, these issues are fairly recent. It was not until the 2000 s that creativity was integrated into Chinese national policies and the fashion sector was listed among the creative industries. Creative industries are defined as industries "in which the products or service contains a substantial element of artistic or creative endeavour." (49) At the turn of the twenty-first century, China's share of world trade was similar to that in $1925,{ }^{(50)}$ when Shanghai was a textile and fashion centre. Today, it is on the verge of retaking this role in the re-emergence of creative fashion, or at least it has set this goal. For instance, in the 12th Five-Year Plan (20112015), some objectives can be seen as beneficial to the fashion industry, although not referred to as such but rather included under the category of "light textile industry." The need to strengthen scientific research and innovation (a term that occurs 39 times) ${ }^{(51)}$ is recurrent in all the sectors mentioned. Furthermore, the speed of urbanisation, retail development, and consumer demand all confirm the government's intention to actively foster a market environment beneficial to consumer and fashion goods.

Foreign companies had proven themselves in global markets with mature brands, retail concepts, and media coverage before entering China, thus facilitating their recognition among Chinese consumers. The range of foreign entrants, from French and Italian luxury brands (Louis Vuitton, Dior, Hermès, Armani, Valentino, etc.) to high street fashion from the U.S. (The Gap, Levi's), Japan (Uniqlo), Sweden (H\&M), and Spain (Zara, Mango) aiming at the new urbanised regions and consumers, is the main challenge facing local entrepreneurs. This trend further accelerated from 2008 to 2012, when more than 32,000 foreign investment projects in wholesale and retail were approved, with an annual growth rate of $20.9 \%$. ${ }^{(52)}$ How did Chinese companies compete?

To illustrate our point, we consider two key categories of local companies: (1) large apparel groups, and (2) small designer brands. The sheer size of the first category allows for the screening of annual reports, the economic press, and retail outlets to compensate for the lack of archives in China. The second category, however, consists of smaller and more confidential brands. This explains the limits of our findings, and the use of the fashion press, blogs, and interviews.

\section{The transformation of large producers into brand owners}

The main reasons why the textile and apparel sector has played such an important role in economic development are: its capacity to absorb large numbers of unskilled labour, low start-up investment cost, and the capital accumulation it permits and which in turn allows it to move into more technologically demanding sectors. In China, the diversification of textile manufacturers into apparel companies has happened faster than else- where. Some garment factories in the 1980s were successful in making major transformations into fashion companies in the ensuing decades. Furthermore, the $12^{\text {th }}$ Five-Year Plan clearly identified the need to establish a strategy to transform the economic structure from export-oriented to domestically-oriented strategies. Following that trend, domestic brands more clearly targeted Chinese consumers.

Youngor (Yage'er 雅戈尔) from Zhejiang Province and Bosideng from Jiangsu Province are two leaders of the menswear market originating in the second half of the 1970s. In 2011 they were respectively the first and fifth domestic apparel brands in terms of sales income. ${ }^{(53)}$ Both gradually adapted their business models to each decade's new challenges, taking the right decisions to survive pressure from foreign entrants and changes in economic policies, social mobility, and the business environment. It should be pointed out that the production of menswear gave birth to the readyto-wear industry in the U.S., Italy, Japan, and China through manufacturing military attire and work-wear either in high-end tailor shops or low-end mass production factories. The last reason is that men's apparel is a stable consumer good that does not depend excessively on fashion trends. As a result, women's apparel was industrialised later in China as elsewhere.

The company behind Bosideng, the country's specialist brand for down jackets (jackets filled with feathers, or natural or synthetic fibres), epitomises the major shifts in the apparel industry, opening a garment factory in 1975 and a store in London in 2012. The Bosideng brand was launched in 1994, 20 years after its foundation, and ranked number one in sales the following year in China's apparel market. It entered a new stage after being listed on the Hong Kong stock exchange on 11 October 2007, expanding into other markets, acquiring existing apparel brands, and investing in retail through the Dakang Department Store to counter the seasonality of winter products. Gao Dekang, the company's chief executive officer and a tailor's son, became one of China's billionaires in 2010 at the age of 58. ${ }^{(54)}$ After opening the London store in 2012, establishing a European headquarters, and purchasing several local British companies, the CEO met British Prime Minister David Cameron in 2013. Cameron "praised Bosideng for blazing a trail in expanding into the British market and said the company's move helped foster the Sino-British relation and bolster the bilateral trade." (55) Selling through 11,000 retail outlets all over China, the company transformed its business model and value chain, and made use of its British base to create value. Through the opening of a design centre in London, products with a higher fashion content and higher prices were meant to be imported back to China to be sold together with "made in China" items. ${ }^{(56)}$ While

49. Richard Caves, Creative Industries: Contracts between Art and Commerce, op. cit., p. 2.

50. Wolfgang Keller, Ben Li, Carol H. Shiue, "China's Foreign Trade: Perspectives from the Past 150 years," The World Economy, Vol. 34, No. 6, 2011, pp. 853-892.

51. 12th Five-Year Plan document, translated by the Delegation of the European Union in China.

52. Ministry of Commerce of the People's Republic of China (MOFCOM), "MOFCOM Held a Press Conference on Retail and Wholesale Industries Promoting Economic Development," 9 July 2013, available at http://english.mofcom.gov.cn/article/newsrelease/press/201307/20130700191 424.shtml (accessed on 15 July 2015)

53. China National Garment Association, "Top 100 enterprises by sales income in China Apparel Industry in 2011," available at www.cnga.org.cn/engl/powerful/top100.asp?ab=sales2011(accessed on 20 August 2015).

54. "No. 828 Dao Dekang and family," Forbes.com, 3 March 2010, available at www.forbes.com/ lists/2010/10/billionaires-2010_Gao-Dekang-family_8ZV7.html (accessed on 15 July 2015).

55. Bosideng press release, company website, 6 December 2013 , available at http://company.bosideng.com/eng/news/corpnews/p131206.pdf (accessed on 15 July 2015).

56. Ellwood Mark, "The New Cachet of 'Made in China'," The Wall Street Journal (online), 24 May 2013, available at www.wsj.com/articles/SB10001424127887324787004578497071619280906 (accessed on 15 July 2015). 
Western brands enter China, this Chinese brand entered Europe and then re-entered its own country with Western know-how as an added value to compete at a higher level of taste and style.

Branding strategies were clearly stated from 2007, such as moving into fashionable down jackets in order to adapt to consumers' changing needs and increasing purchasing power. "Down apparel today has evolved to become light and slim with trendy and fashionable designs that appeal to affluent consumers, who boast higher spending power." (57) In March 2008, the Bosideng corporate structure consisted of the private equity of Mr. Gao Dekang, as well as $7.71 \%$ in public equity from the Chinese government under "Olympics Investment." (58) As of March 2011, Bosideng Group managed 7,579 retail outlets selling six brands, and had 2,690 full-time employees. ${ }^{(59)}$ In comparison, the Spanish Inditex Group managed 6,683 stores in 54 markets as of January 2015, and employed 137,054 people. ${ }^{(60)}$ In spite of Bosideng Group's four brands holding $37.8 \%$ of the PRC's down jacket market in 2013, it faced new challenges with the easing of the market and the arrival of new competitors such as the giant Japanese retailer Uniqlo (Fast Retailing Group) aimed at a similar market segment. Furthermore, "rising raw material prices, labor costs and rental costs gradually eroded profit margins," along with "the explosion of e-commerce in the country." These factors may explain why Mr. Gao stepped down as CEO in 2014. (61) It also signalled the end of an era. The entrepreneurs' generation of the 1990s is ready to let market-oriented and consumer-driven managers take the lead.

In the women's apparel market, Lily is a growing company launched by the state-owned Silk Group in 2002. Today, its ambition is to become one of the ten leaders of the local fashion market, according to the chief designer, Mrs. Li Lun. In fact, she mentioned that the current top brands in mid-market Chinese apparel were Vero Moda and Only, both belonging to the Danish group Best Seller mentioned earlier. Interestingly, Best Seller's Chinese factories produce for both local retail and export to Europe under the same labels, but make a clear distinction in quality standards. (62) For Lily, quality is a key success factor, and the will to become a leader motivates the creative team. For the chief designer, leadership is measured in terms of market share, volume of goods sold, and the number of retail outlets rather than in terms of fashion statement. ${ }^{(63)}$ Without participating in local fashion weeks, bi-annual fashion shows are held for their network of retailers and franchisees. Interestingly enough, the company executives acknowledged that Lily started as a clothing company and only began investing in branding strategies since 2012. (64) Compared to fashion companies in mature markets, this is an unusual path.

More recently, in the silk production sector, new events likewise confirm the movement by Chinese players towards branding, upgrading, and design as a strategy for differentiation in the domestic and global markets. In July 2014, the Hangzhou-based silk producer Wensli Group appointed a French executive as the CEO of one of its companies, ${ }^{(65)}$ Wensli Silk Culture Company. This decision followed the buyout in 2012 of a factory in France's Lyon region (famous for silk), which was producing for the world-renowned Hermès brand, and also enables the group to distribute high-end products in Europe.

\section{Small designer brands}

The second category of companies we examined to illustrate the transition of the clothing industry into a fashion industry are the designer brands. The obstacles they face in terms of production, distribution, finance, man- agement, and communication hinder their development and need to be addressed. A few started emerging in the second half of the 1990s, and more prominently in the 2000s, but they have attracted more notice abroad than in China. ${ }^{(66)}$ In terms of size, these companies are often small or even insignificant compared to the afore-mentioned gigantic apparel makers. We may wonder if they are in the same industry, as their challenge is of another sort. "Chinese designers have creativity but not enough economic power to compete with established brands." (67) Indeed, most young designers lack access to funding to hire enough employees, and get rejected by factories because of their small orders. The industrial infrastructure does not welcome creative SMEs and the elaborate manufacturing and quality requirements that result from their niche positioning. Even after ten years, some Shanghai designers still rely on teams of fewer than ten people. ${ }^{(68)}$ Some have managed to open their own workshops to produce small collections in collaboration with other designers to create synergies. Others are able to show in Paris, like Masha Ma, a designer's brand launched in 2008, and are often in the media. ${ }^{(69)}$ Yet another small company, La Chambre Miniature, illustrates the current situation. The two founders and brothers, Hong and James Chang, trained in London and Vienna, launched a conceptual brand about ten years after working in the West. Originally from Taiwan, they are looking for the essence of Chinese culture and a harmonious blend of different influences. They confirm the lack of a system and support for fashion brands outside of the official Shanghai Fashion Week. ${ }^{(70)}$

In terms of communication, emerging designers need to be identified by buyers and the press, if not potential investors. Since the end of the 2000s, several websites and blogs have been playing the role of intermediaries and cultural gatekeepers ${ }^{(71)}$ in place of traditional printed magazines. Their low budgets explain the heavy use of social media. Celia B., an up and coming creative designer brand launched in Shanghai in 2012 by Spanish designer Celia Bernardo, formerly with Zara, relies mainly on social media. Bernardo has been able to win journalists' acclaim and prizes with a low budget, but a lack of legal framework has allowed her landlord to increase the design studio's rent, and her business remains fragile. (72) ZucZug

57. Bosideng 2007-2008 Annual Report, p. 9.

58. Ibid., p. 2 .

59. Consultation of six Bosideng annual reports from the first stock exchange registration in 2007 to 2013.

60. Inditex Group financial results press release, 18 March 2015.

61. Russell Flannery, "Chinese billionaire Gao Dekang Steps down as CEO at Apparel Giant Bosideng," Forbes.com, 14 May 2014, available at www.forbes.com/sites/russellflannery/2014/05/14/chinesebillionaire-gao-dekang-steps-down-as-ceo-at-apparel-giant-bosideng (accessed on 15 July 2015).

62. Interview with Mr. Laurent Cochet, supply chain consultant in apparel, Shanghai, January 2014.

63. Interview with Mrs Li Lun, Lily's brand chief designer, Shanghai, December 2013

64. Lily company presentation, Jiaotong University conference on branding, Shanghai, May 2014.

65. Yan Yiqi, "Wensli has designs on European Silk Market," China Daily USA, 3 July 2014.

66. Books on Chinese designers are written by Westerners, or Chinese scholars based abroad.

67. Gianluca Brozzetti, Chief Executive of the Italian luxury brand Roberto Cavalli, interviewed in Milan by Antonella Ciancio, "Milan Fashion Awaits Chinese Design Boom," Reuters, 27 February 2011.

68. Helen Lee, designer, interviewed in Shanghai by Erica Ji, "Fashion pioneer Helen Lee Reflects on Decade of Design in China, Jing Daily online (The business of luxury and culture in China), 13 September 2013.

69. Hung Huang, "ChinaFile: Made in China Branded in Paris," Women's Wear Daily, 7 March 2012.

70. Interview with Hong Chang and James Chang, designers of La Chambre Miniature, Shanghai, December 2013.

71. A term used by Richard Caves and Regina L. Blaszwyck, it refers to people who have the legitimacy or authority to evaluate, approve, or criticise the work of artists and fashion designers, and as such can influence the final consumer.

72. Interview with Mrs. Celia Bernardo, designer, Shanghai, April 2015. 
(Suran 素然), a Chinese brand with both design content and commercial appeal launched in 2002, operated 73 stores aiming at Chinese trendsetters in 2012. This is a small number by Chinese standards. In 2008, the first exhibition of Chinese fashion designers in Europe was showcased in London's Victoria and Albert Museum, featuring Ma Ke, Zhang Da, and Wang Yiyang among others. Research on Chinese designers is still quite confidential. ${ }^{(73)}$ Gemma Williams, a fashion curator and author, was advised by Chinese journalists to identify 41 Chinese fashion designers for her recent book. She argues that a new group of talented designers are currently redefining the boundaries of design. ${ }^{(74)}$

As far as consumer demand is concerned, the search for creative items contrasts sharply with the difficulties of local designers that we described. It seems as if alternative, off-the-track consumption patterns stemming from higher incomes, rapid urbanisation, and social change are not addressed rapidly enough. As a matter of fact, some consumers in large cities have lost interest in well-known fashion brands. Over the last five years, consumers who used to buy Louis Vuitton have turned to boutique brands. It is a matter of distinguishing oneself from others, and buying exclusive but not expensive Chinese designs. ${ }^{(75)}$ In spite of this burgeoning trend toward buying local designs, the gap between creative SMEs and the infrastructure and spirit of mass production inherited from decades of collectivisation seems wider than in other countries. The question of the efficiency of centralised policies to resolve the above issues is at the heart of the creative development of Shanghai. Can fashion creativity be planned?

\section{The fashion eco-system and its intermediaries}

Fashion capitals emerge from an eco-system that unravels over a long period of time in a specific location, and can be characterised by similar factors (Caves, Kawamura, Breward). Among them is the presence of intermediaries, a term that bears several definitions. According to Spulber, an intermediary is a firm that coordinates the actions of buyers and sellers. ${ }^{(76)}$ Fashion business historian Regina Lee Blaszwyck defines fashion intermediaries as "networks of professionals that analyse the market place." (77) We may combine both definitions to describe the players observable in the environment of Shanghai fashion that contribute to structuring its new creative fashion output. In combination with fashion core companies (producers, designers, and retailers) that provide goods to consumers, fashion intermediaries are organisations and individuals that are considered part of the fashion eco-system and participate in its development, diffusion, and promotion. Although not as mature as other world capitals, Shanghai gathers together public and private firms, organisations, and educational institutions that work with or support fashion producers, buyers, media, ${ }^{(78)}$ and consumers. They are involved in import/export services, design, media, consulting, trade, and education, among other areas. Within the limits of this paper, we will highlight four types of intermediaries: (1) the trade, (2) fashion associations, (3) forecasting services, and (4) fashion education institutions.

Concerning trade, the 1990s saw the launch of major projects by the municipal government, with an impact on the fashion business and retail. Shanghai Mart was a significant player in the industry, situated as an intermediary between producers and retailers, and since then has held a unique role in the fashion industry of Shanghai and the region. Built in the
Shanghai Hongqiao Economic and Technological Development Zone beginning in 1993 and opened in 1999, it was modelled on American malls and was the first permanent trade exhibition centre in China. It offers $200,000 \mathrm{~m}^{2}$ of show rooms, ${ }^{(79)}$ renting space to large corporations such as Walmart, Carrefour, and C\&A, as well as SMEs in the fashion and accessories business. It aims at facilitating exchanges between players, and offers temporary exhibitions to further enhance exchanges, as well as training programs and fashion show facilities. Twice a year it also welcomes shows by design students from nearby Donghua University. It aims at creating an international platform for product sourcing, and at promoting trade opportunities. Other services relate to customs clearance, garment quality inspection, and license applications. The business model is quite unique for Shanghai, as it created a platform between multiple actors in both the Bto-B and B-to-C arenas. It also aims at understanding consumer needs, and promotes its member companies to television and shopping channels through major e-commerce sites such as Alibaba and Taobao. As an intermediary, Shanghai Mart also selects firms according to the quality of their products and their reputation in the mid-market range.

Behind this firm stands a large real estate company, and more specifically a businessman, Mr. Tao. Born in Ningbo, Jiangsu Province, Mr. Tao moved to Singapore at the age of ten and became a powerful real-estate tycoon in Southeast Asia. As head of the Shin Kar Group, he established several hotels and commercial centres in Sri Lanka, Singapore, and mainland China. Aged 97 in 2014, he still held meetings and visited Shanghai Mart, as it was one of the symbolic real estate projects of the 1990s in Shanghai and is still an important place for each Shanghai mayor to come and visit. ${ }^{80)}$ However, 15 years after its opening, the business model faces challenges. It is not as profitable as it could be, and it has been seeking to provide new business opportunities since investor cash input began dwindling in 2005 . A visit to the premises in January 2014 confirmed a lack of tenants, as several booths remained empty.

Fashion associations have a long tradition of being intermediaries. Totally or partly controlled by the government, they operate on the national, regional, and municipal levels. On the national level, one of the most prominent associations is the China Fashion Garment Association (Zhongguo fuzhuang xiehui 中国服装协会), founded in Beijing in 1991. Members consist of various industry players such as fashion designers, brand makers, fashion media, and modelling agencies. It is organised around committees that include an Expert Committee, Art Committee, Academic Committee, Models Committee, Fashion Media Committee, Technical Committee, Display Committee, and Brand Committee. ${ }^{\left({ }^{21}\right)}$ Its role is to serve as a bridge

73. Christine Tsui, China Fashion: Conversations with Designers, Oxford, New York, Bloomsbury Academic, 2010.

74. Gemma Williams, Fashion China, op. cit.

75. Laurie Burkitt, "Is ZucZug China's Marc Jacobs?," The Wall Street Journal, 11 May 2012, available at www.wsj.com/video/is-zuczug-china-marc-jacobs/60FE2984-3963-4953-99A2-0235B90C7 ED4.html (accessed on 15 July 2015).

76. Daniel F. Spulber, Market Microstructure: Intermediaries and the Theory of the Firm, Cambridge, Cambridge University Press, 1999, pp. xiii-xv.

77. Regina Lee Blaszwyck (ed.), Producing Fashion: Commerce, Culture, and Consumers, op. cit.

78. On fashion and media, see Roland Barthes, Le système de la mode (The Fashion System), op. cit., and Agnès Rocamora, Fashioning the City: Paris Fashion and the Media, London \& New York, I.B. Tauris, 2009

79. Interview with Mrs. Mandy Tang, Shanghai Mart Marketing Director, Shanghai, January 2014

80. Same interview with Mrs. Mandy Tang

81. China Fashion Association website (Zhongguo fuzhuang xiehui wang), available at www.cnga.org.cn (accessed on 15 July 2015). 
between the industry and the government, companies, and society at large. The four departments are: industry, information, exhibitions, and coordination, representing eight categories such as ladies' wear, men's wear, etc. Their services in terms of marketing, research, and technique provide support to about 1,500 member companies. The association publishes a magazine, Zhongguo fuzhuang (Apparel World) that explains government policies, legal changes, economic trends, and the evolving local and international markets to executives and decision-makers. ${ }^{\left({ }^{82}\right)}$ At the municipal level, Shanghai fashion associations can make use of the city's 1920s reputation to promote local brands and compete with Beijing. It has demonstrated a decisive move towards enhancing "place of origin," one of the keys of fashion branding. For instance, Shanghai Fashion Designers Association (SFDA) events are organised both locally and abroad. In 2013, an event was organised in London featuring some of the best Shanghai designers under the "Design by Shanghai" project to differentiate them from the "made in China" image. The event was reported in the specialist media: "Design by Shanghai is committed to establishing a fresh new Shanghai design concept in the international fashion industry and drawing more attention from international media and fashion celebrities in order to promote the international development of domestic designers." (83)

Fashion forecasting is a cornerstone of the development of a modern fashion industry. It played a prominent role in the industries of Europe, the U.S., and Japan, especially from the 1960s onward. Trend offices worked with actors on the entire value chain and performed the role of "mediator" between the press, the industry, and buyers in a "circular manner," argues business historian Thierry Maillet. ${ }^{(84)}$ Today they provide services to manufacturers and buyers to anticipate social and consumer trends. In Shanghai, this business is in its infancy, and a few foreign companies have burgeoned in the last few years. For instance, the British WCSN trend forecasting office established a base in Shanghai in 2010. It analyses the local fashion scene from the retail and consumer perspectives, and sends regular reports to the company's London headquarters, which gathers data from its worldwide offices and provides information to fashion producers, fashion schools, trade federations, and magazines, as well as information about China to world professionals. ${ }^{(85)}$ Other world players have opened branches in Shanghai with similar purposes: Peclers (WPP Group), Nelly Rodi, and Promostyl from France.

As far as fashion education is concerned, China's large coastal cities have dominated contact with the outside world, and have integrated international educational standards and influence more quickly than other regions. ${ }^{\left({ }^{86}\right)}$ As a coastal city and China's most Westernised region in the pre-1949 period, and the heart of socialist industrialisation in the 1950s and 60 s, Shanghai and its universities have played a major role in the education of leaders in the clothing and textile industry. Donghua University has been one of its pillars since its founding in 1952, building its reputation on its expertise in textile engineering. The design departments have been gradually reinforced through international partnerships with Bunka University from Tokyo, the Fashion Institute of Technology from New York, and more recently with the London College of Fashion. The link between universities and companies is at the heart of innovative clusters. After Tongji University, which is surrounded by architectural firms, Donghua University was the second university in Shanghai to relate its expertise to a burgeoning business. During Fashion Week in April 2012, the municipal government announced a project to create a Fashion Industry zone next to Donghua University, covering almost 15 square kilo- metres in the western part of Changning District. It was declared that fashion studios would be able to capitalise on Donghua University zones, and graduates would be encouraged to open studios in that area. Nonetheless, it was also mentioned that the expected revenue growth of incubator companies was $17 \%$ a year and would hit 200 billion yuan in 2015. ${ }^{(87)}$ It could be argued that the objective of financial return on investment imposed on young designers may foster more commercial products than creative ideas.

The local education system has been slow to integrate society's needs. Individuals who find they have not been prepared for the fast pace of the city and international standards of design and creativity turn to international education at home or abroad. As a consequence, in tandem with state-controlled universities, an increasing number of foreign fashion schools have opened since the 2000s, located on Chinese campuses or as stand-alones. Raffles from Singapore is located on the Donghua campus, while France's IFA Fashion School is at the Shanghai University of Engineering Sciences. Their teaching methodology differs radically from formal Chinese education, where rote learning is still prevalent along with a focus on industrial skills and theory rather than on free creation and aesthetics. As a result, the level of design output has been slow to gain momentum, and explains the increase in Chinese students enrolling in foreign fashion schools. Conversely, foreign programs emphasise a practical approach, as most instructors are foreigners with professional experience. Furthermore, they can help students deploy their creativity, self-expression, and individuality and dig into their cultural roots to stimulate novel ideas. ${ }^{(88)}$ They also provide fashion management courses through regular undergraduate, post-graduate, and continuing education programs. To remain independent of state control, and to allow more freedom of action, some schools have opened outside of campuses. This is the case with Istituto Marangoni, an 80-year-old school from Milan with campuses in Paris and London, which opened in Shanghai in 2013. In 2015, the UK fashion publisher Condé Nast, famous for its Vogue and Glamour magazines, announced the opening of a training centre in fashion and design following the opening of a centre in London in 2013. As with Japanese designers from the 1970s onward, experience studying abroad is a key step in the transition toward acquiring creative skills. Japanese design leader Yohji Yamamoto, for instance, studied in France and New York to master Western pattern-making and creation in foreign fashion houses before launching his company in 1972, and his cuttingedge aesthetic and design concepts in the 1980s. Likewise, the current wave of Chinese people studying in Europe, the U.S. and Japan, will be instrumental for the next generation of designers.

82. Idem.

83. Landon Du, "Design by Shanghai immerses Audiences with Fashion Collections from 11 Chinese Designers," 18 September 2013, available at www.prnewswire.com (accessed on 15 July 2015).

84. On the history of forecasting, see Thierry Maillet, Histoire de la Médiation Entre textile et Mode en France: Des Échantilloneurs aux bureaux de style 1825-1975 (History of Mediation Between Fashion and Textile in France: From samplers to style offices 1825-1975), unpublished PhD thesis, EHESS, 2013.

85. Interview with Mrs. Irene Lee, sales manager of WGSN branch, Shanghai, April 2013.

86. Ruth Hayhoe, "Shanghai as a Mediator of the Educational Open Door," Pacific Affairs, Vol. 61, No. 2, 1988, pp. 253-284.

87. Zang Kejia, "Fashion industry zone to crop up in Changning district," Shanghai Daily, 23 April 2012.

88. Interview with Mrs. Cathleen Gay, fashion designer and former professor in IFA Fashion School, Shanghai, 20 June 2015. 


\section{Conclusion}

Since the heydays of Shanghai in the 1920s and 30s, the potential for a new creative revival has never been as great as it is today. However, as a vital part of the Chinese economy since the 2000s, creative industries require more sophisticated levels of infrastructure, management skills, education, individual talent, and culture. Furthermore, we may argue that the constraints of history and the Cultural Revolution, a planned economy, the external pressure of mature foreign entrants, the speed of technology and social media, social responsibility, and consumer demand form a set of complex challenges for companies investing in creative and cultural industries. These challenges also create opportunities. At the company level, large groups have moved towards integrating logistics systems with digital media technology, and investing in R\&D and human capital. Burgeoning designers and design-oriented SMEs, although struggling to survive in a mass-oriented society and market, increasingly answer the needs of consumers. On a wider scale, the dynamics of the city of Shanghai are answering the need to "write a brilliant (...) chapter of the Chinese Dream." (89) Municipal policies, such as the UNESCO Creative Cities membership, the organisation of the World Expo in 2010, and a network of creative clusters, have created a catalyst. The bustling retail scene, a gigantic fashion and luxury market, and a network of fashion intermediaries have accelerated the birth of a fashion hub in a city with a credible name. The outcome of thriving financial, economic, social, and cultural development may be the rise of an influential fashion system, and the recognition of Shanghai as the sixth world fashion capital.

I Sabine Chrétien-Ichikawa is a business historian, and lectures at Shanghai Normal University and at European business schools.

Humanities and Communication College, Shanghai Normal University, 100 Guilin Road, Xuhui, Shanghai, 200234 (sabineichi@hotmail.com). 